\title{
Correlation between Sau1 Restriction and Modification Complex Type and Coagulase Serotype or SCCmec Type of Staphylococcus aureus
}

\author{
So Yeon Kim, Soo Myung Hwang and Kyung Soo Chang ${ }^{*}$ \\ Department of Clinical Laboratory Science, Catholic University of Pusan, Busan, Korea
}

\begin{abstract}
Staphylococcus aureus coagulase serotype I to VIII isolated from clinical samples could be classified into two groups, methicillin-sensitive $S$. aurues (MSSA) and methicilln-resistant S. aurues (MRSA), by antibiotics susceptibility and existence of mecA which is a gene related with methicillin resistance. Coagulase serotype I, VI, and VIII were MSSA which showed different antimicrobial susceptibility. Coagluase serotype II-V and VII were MRSA in which mecA and SCCmec were detected. To analyze Saul restriction and modification (R-M) complex types by coagulase type and SCCmec type, saulhsdR, saulhsdM and saulhsdS genes involved in Saul R-M complex were detected by PCR, we found five complex types such as M1, $\mathrm{R}_{2} \mathrm{M} 2$, R2M2, $\mathrm{R}_{2} \mathrm{M} 2 \mathrm{~S} 1$, and R2M2S2. Coagulase serotype I, VI, and VIII of MSSA were M1, $\mathrm{R}_{2} \mathrm{M} 2$ and $\mathrm{R}_{2} \mathrm{M} 2$, respectively. SCCmec type II and coagulase serotype II, SCCmec type III and coagulase serotype III, SCCmec type IV and coagulase serotype V, and SCCmec type IV and coagulase serotype IV, VII of MRSA were Sau1 R-M complex type $\mathrm{R}_{2} \mathrm{M} 2 \mathrm{~S} 1, \mathrm{R} 2 \mathrm{M} 2$, R2M2, and R2M2S2, respectively. Taken together, correlation between Sau1 R-M complex types and coagulase or SCCmec types of S. aureus was found.
\end{abstract}

Key Words: Staphylococcus aureus, Sau1 restriction-modification (R-M) complex type, Coagulase serotype, SCCmec type, $h s d$ gene

\section{서 론}

화농성 감염의 주 원인균 중 하나인 Staphylococcus aureus는 그람 양성 세균으로 원외 및 원내 감염 (nosocomial infection)을 일으키는 주요 세균으로 중증인 균혈증과 골수염을 일으킨다 $(1,2)$. Methicillin-resistant S. aureus (MRSA)가 출현하면서 원내 감염 또는 지역사 회 감염 (community-acquired infection)에 심각한 문제로 인식되고 있다 (3 5).

Penicillin계 항생제는 S. aerues의 세포벽 합성을 방해 하여 항균작용을 나타내는데, penicillinase를 생성하는 균

Received: September 3, 2010/ Revised: September 23, 2010

Accepted: September 29, 2010

*Corresponding author: Kyung Soo Chang. Department of Clinical Laboratory Science, Catholic University of Pusan, Busan 609-757, Korea. Phone: +82-51-510-0565, Fax: +82-51-510-0568

e-mail: kschang@cup.ac.kr

** This research was supported by the research fund of the Catholic University of Pusan.
주에 대해선 항균력이 없다. Methicillin은 penicillinase에 안정한 penicillin으로 MRSA 감염 치료에 유효하게 사용 되었다. 그러나, 1960년대 MRSA가 등장하고, 대부분의 항생제에 내성을 가진 S. aureus가 나타났다 (6). MRSA는 methicillin, nafcillin, oxacillin, cloxacillin 등 penicillinase에 안정한 제제에 내성인 균을 뜻하며, 그 내성 기전은 새 로운 penicillin 결합 단백인 (penicillin binding protein, PBP) 인 PBP $2 \mathrm{a}\left(2^{2}\right)$ 의 생성에 의한다. Methicillin 내성 유전자가 들어 있는 $\mathrm{SCCmec}$ 은 염색체에 위치하지만 획득한 것 이다 (7). 항생제 사용이 많아지면서 병원균들도 내성인 균주가 생겨나기 시작했는데 특히 MRSA는 대부분의 항 생제에 내성을 보여 극히 소수의 항생제로만 치료가 가 능하다. 더욱 심각한 것은 원내 감염을 유발하는 병원 균 중 MRSA는 가장 빈번히 나타나는 세균이고, 면역력 이 약한 환자나 노약자에게는 치명적인 감염을 일으킬 수 있다. 면역력이 약화된 환자의 증가로 인해 항생제의 사용이 잦고 이로 인해 내성 세균 감염률도 높게 된다. MRSA에서는 흔히 heterogeneous resistance라 하여, 이는 
한 균주 중 극히 일부 세균만이 methicillin에 내성을 발현함을 뜻한다. 그러나, 근래 우리나라에서 분리되는 MRSA는 대부분이 homogeneous형으로 한 균주 중 대부 분의 세균이 methcillin에 대한 $\mathrm{MIC}$ 가 높다 (8).

S. aureus의 병독성 인자 중 세포외 분비단백성분으로는 coagulase, Panton-Valentine leukocidin (PVL), staphylococcal enterotoxin, toxic shock syndrome toxin-1 (TSST-1) 등이 있으 며, 이중 coagulase는 prothrombin을 활성화하여 섬유소원 을 섬유소로 변환시켜 혈장을 응고시키는 효소로, 현재까 지 사람에서 분리된 균주에서는 8 종의 혈청형 (I-VIII)과 동물에서 분리된 균주에서는 2 종의 혈청형 (IX-X)이 보 고되었다 (4, 9 12). 1980년부터 1994년에 분리된 MRSA 의 SCCmec type과 coagulase type을 비교하면 항생제 내 성 정도가 상당히 높은 coagulase II형 및 SCCmec type IV 형이 대부분을 차지하였다 $(13,14)$.

MRSA의 병원성 유전자 및 항생제 내성 유전자는 mobile genetic elements (MGE)의 수평전파에 의해 확산 된다. 약 $15 \%$ 의 S. aurues는 bacteriophage, transposons, plasmid와 같은 $\mathrm{MGE}$ 를 가지고 있다. 이런 $\mathrm{MGE}$ 로 세균 종간 확산을 조절할 수 있는 것은 세균의 유전자 조작 및 진화에 달려있다 (15 17). 세균이 외부의 DNA를 획득 후 이의 발현을 조절할 수 있는 한 가지 방법은 restriction-modification (R-M) system을 이용하는 것이다. R-M system은 크게 4가지 형이 존재하며, type I R-M system은 구조적인 복합체를 형성하며 endonucleolytic activity를 위해 ATP, Mg2+와 S-adenosylmethionine (SAM) 이 필요하다. Type II 제한효소는 $100 \mathrm{kDa}$ 보다 작은 분 자량으로 열에 민감하고 endonucleolytic activity를 위해 $\mathrm{Mg} 2+$ 만 필요로 하며, 핵산의 특정 부위만을 잘라 현재 분자생물학 연구에 널리 사용하고 있다 $(17,18)$. SauI type I R-M system은 염색체에 위치하며 한 개의 $h s d R$ (restriction) 유전자와 두 개의 $h s d M$ (modification)과 $h s d S$ (specificity) 유전자를 가지고 있으며, 이들은 M2S 또는 $\mathrm{R} 2 \mathrm{M} 2 \mathrm{~S}$ 와 같은 복합체를 형성한다. M2S는 SAM으로부터 adenine 잔기에 메칠기 전이를 촉매하며, 제한효소로부터 $\mathrm{DNA}$ 를 보호한다. R2M2S 복합체는 제한효소로, target 염 기서열 중 메칠기가 붙어있지 않은 부분을 인식하여 비 특이적으로 자른다. S subunit는 메칠화가 되거나 제한효 소로 잘라져야 할 특이 염기서열이 있는 지를 인식한다 $(17,18)$.

저자들은 이전 연구에서 coagulase type과 SCCmec type
과의 상관성을 밝혀내었다 (7). 그러나, coagulase type에 따라 어떻게 SCCmec type이 다른가에 대한 해답을 찾지 못했다. 따라서 본 연구에서는 항생제 내성 유전자의 전이 및 용원화에 영향을 미치는 SauI R-M system에 포 함되어 있는 세 개의 유전자인 sauIhsdR, sauIhsdM 및 saulhsdS를 분석하여 coagulase type별로 어떠한 복합체를 형성하며, $\mathrm{SCCmec}$ 유전자 및 methicillin 내성과의 상관 성을 규명하고자 본 연구를 수행하였다.

\section{재료 및 방법}

\section{실험균주 및 표준균주}

사람의 가검물에서 분리 동정된 S. aureus coagulase type I VIII형 균주를 황수명 (Catholic University of Pusan, Busan, Korea)으로부터 분양 받아 실험균주로 사용하였으 며, coagulase type별로 5균주 이상을 실험하였다. Coagulase 혈청형 실험은 8종의 항 혈청 (Denk Seiken Co, Tokyo, Japan)을 사용하여 Hwang 등의 방법을 이용하여 시행하 였다 (13). 균주 중 coagulase type I, VI, VIII은 MSSA이었 으며, II-V과 VII은 MRSA이었다. 표준균주로는 ATCC에 서 분양받은 S. aureus (ATCC25923)를 사용하였다. 표준 균주 및 실험균주는 mannitol agar (MSA, BD Diagnostics, Hunt Valley, MD, USA) 및 nutrient agar (NA, BD Diagnostics) 에 평판배양한 후 순수 집락을 brain heart infusion (BHI, BD Diagnostics) broth에 배양하여 coagulase test, 항생제 감수성 시험 및 genomic DNA 추출을 수행하였다.

\section{항생제 감수성 시험}

항생제 감수성 검사는 Kirby-Bauer 항생제 감수성 시 험 및 Vitek GPS 451 kit을 사용하여 항생제 감수성 시험 을 시행하였다. CLSI법은 BHI broth에서 배양된 표준균 주 및 시험균주를 $0.45 \% \mathrm{NaCl}$ 을 사용하여 McFarland 0.5 $\left(1.5 \times 10^{8} \mathrm{CFU} / \mathrm{ml}\right)$ 에 맞추고 $100 \mu \mathrm{l}$ 을 Muller-Hinton agar 에 접종한 후 항생제 disk를 올려놓고 $37^{\circ} \mathrm{C}$ 에서 24 시간 또는 48시간 배양하여 항생제 세균 발육저지원의 직경을 재어 CLSI 판독표를 기준으로 감수성을 결정하거나 자동 미생물분석기의 GPS $451 \mathrm{kit}$ 를 이용하여 항생제 감수성을 비교하였다.

\section{Genomic DNA의 추출}

S. aureus로부터 genomic DNA의 추출은 NA에서 순수 
S. aureus 집락을 tryptic soy broth (TSB)에 균을 풀어 24 시간 배양 후 배양액을 $4^{\circ} \mathrm{C}$ 에서 $12,000 \mathrm{rpm}$ 으로 10 분간 원심분리한 후 상층액을 제거한 후 lysozyme solution $(0.0015 \mathrm{~g} / \mathrm{ml}) 300 \mu \mathrm{l}$ 를 첨가하여 진탕교반하였다. 진탕배 양기에서 $37^{\circ} \mathrm{C}$ 로 1 시간 반응한 후 $10 \% \mathrm{SDS}$ 용액을 300 $\mu \mathrm{l}$ 첨가한 후 $-70^{\circ} \mathrm{C}$ 와 $65^{\circ} \mathrm{C}$ 에서 15 분씩 동결용해를 각 3 회 실시하였다. Phenol/chloroform/isoamyl alcohol (PCI, 25:24:1) $700 \mu 1$ 를 첨가한 후 30초간 진탕교반한 후 12,000 $\mathrm{rpm}$ 으로 15 분간 원심분리하였다. 상층액을 새 tube에 옮 긴 후 다시 PCI 용액 $700 \mu \mathrm{l}$ 를 섞어 진탕교반한 후 원심

Table 1. Primers and predicted sizes of PCR products for SCCmec type and Sau1 R-M complex genes

\begin{tabular}{|c|c|c|c|c|}
\hline \multicolumn{2}{|c|}{ Primer names } & Primer sequence (5' to $3^{\prime}$ ) & Amplified sizes & Target gene \\
\hline \multicolumn{3}{|c|}{ Primers for SCCmec type } & & SCCmec type \\
\hline \multirow{2}{*}{ A } & CIF2 F2 & TTCGAGTTGCTGATGAAGAAGG & \multirow{2}{*}{495} & \multirow{2}{*}{ I } \\
\hline & CIF2 R2 & ATTTACCACAAGGACTACCAGC & & \\
\hline \multirow{2}{*}{$\mathrm{B}$} & KDP F1 & AATCATCTGCCATTGGTGATGC & \multirow{2}{*}{284} & \multirow{2}{*}{ II } \\
\hline & KDP R1 & CGAATGAAGTGAAAGAAAGTGG & & \\
\hline \multirow{2}{*}{$\mathrm{C}$} & MECI P2 & ATCAAGACTTGCATTCAGGC & \multirow{2}{*}{209} & \multirow{2}{*}{ II, III } \\
\hline & MECI P3 & GCGGTTTCAATTCACTTGTC & & \\
\hline \multirow{2}{*}{$\mathrm{D}$} & DCS F2 & CATCCTATGATAGCTTGGTC & \multirow{2}{*}{342} & \multirow{2}{*}{ I, II, IV } \\
\hline & DCS R1 & CTAAATCATAGCCATGACCG & & \\
\hline \multirow{2}{*}{$\mathrm{E}$} & RIF4 F3 & GTGATTGTTCGAGATATGTGG & \multirow{2}{*}{243} & \multirow{2}{*}{ III } \\
\hline & RIF4 R9 & CGCTTTATCTGTATCTATCGC & & \\
\hline \multirow{2}{*}{$\mathrm{F}$} & RIF5 F10 & TTCTTAAGTACACGCTGAATCG & \multirow{2}{*}{414} & \multirow{2}{*}{ III } \\
\hline & RIF5 R13 & GTCACAGTAATTCCATCAATGC & & \\
\hline \multirow{2}{*}{ G } & IS431 P4 & CAGGTCTCTTCAGATCTACG & \multirow{2}{*}{381} & \multirow{2}{*}{ IA } \\
\hline & pUB110 R1 & GAGCCATAAACACCAATAGCC & & \\
\hline \multirow{2}{*}{$\mathrm{H}$} & IS431 P4 & CAGGTCTCTTCAGATCTACG & \multirow{2}{*}{303} & \multirow{2}{*}{ IIIA } \\
\hline & pT181 R1 & GAAGAATGGGGAAAGCTTCAC & & \\
\hline \multicolumn{3}{|c|}{ Primer for Sau1 R-M complex genes } & & Saul gene type \\
\hline \multirow{2}{*}{\multicolumn{2}{|c|}{$\begin{array}{l}\text { hsdM1-FL } \\
\text { hsdM1-RL }\end{array}$}} & TTA GCT TCA AAG ATG GCA GT & \multirow{2}{*}{1,577} & \multirow{2}{*}{ SaulhsdM1 } \\
\hline & & GGG AAC CTC AAC TCT GGC AC & & \\
\hline \multicolumn{2}{|c|}{ hsdM2-F } & CCT GGG AAT CTC AAC TCT GG & 1535 & SaulhsdMO \\
\hline hsdM & & GAC ATT CAC CCA ATC CTG AC & & \\
\hline hsdR1 & & CGA AAC AAG CGT ATT GTT GC & $2=0$ & C \\
\hline hsdR1 & & TGC TCT ACA ACT TGT TCC AC & 250 & sautnsant \\
\hline hsdR2 & & GCG TTG ATT GTA TTC GGG AC & 2810 & Saulb $d R 2$ \\
\hline hsdR2 & & CCT ACA CTA ATC TGA CGA GG & & \\
\hline hsdS1 & & CAA CGG CAT ACC ATT TTT AAG & 207 & $\mathrm{C}$ \\
\hline hsdS1 & & AGA CCT TCT CGA CTA CCT C & 521 & Santinsast \\
\hline hsdS2 & & CAA TTA ATA GGT TGT TAT CA & & \\
\hline hsdS2 & & ATG CAT ACC TGA AAG AAC TT & & 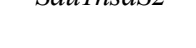 \\
\hline
\end{tabular}

Reference, Cha, et al. (7), Waldron, et al. (18) 
분리하였다. 상층액을 새 tube에 옮긴 후 상층액의 2.5 배 volume의 $100 \%$ 에탄올을 첨가한 후 $-20^{\circ} \mathrm{C}$ 에서 2 시간 침전시켰다. $4^{\circ} \mathrm{C}$ 에서 $12,000 \mathrm{rpm}$ 으로 20 분간 원심한 후 $70 \%$ 에탄올로 세척하였으며, 실온에서 건조한 후 $\mathrm{TE}$ buffer로 녹여 농도를 측정한 후 PCR template로 사용하 였으며, $-20^{\circ} \mathrm{C}$ 에서 보관하여 사용하였다.

$\mathrm{SCC} m e c$ type 및 Saul R-M complex genes 검출 을 위한 PCR

S. aureus coagulase type별 methicillin에 대한 내성 및 유 전자 전이에 관여하는 SauI R-M complex 유전자를 분석 하기 위해 coagulase type I VIII로부터 추출한 genomic DNA를 이용하여 PCR를 수행하였다. Methicillin 내성 유 전자인 $m e c \mathrm{~A}$ 유전자를 증폭하기 위한 primer는 GenBank 에 실린 염기서열에 따라서 Bio ToolKit 320 의 Primo DOP 3.4 (Chang Bioscience, Castro Valley, CA, USA)를 이용하여 설계하였으며, $\mathrm{SCCmec}$ 유전자를 증폭하기 위한 primer 는 Cha 등 (7)이 사용한 primer의 염기서열에 따라서 제 작하였으며, SauI complex 유전자를 증폭하기 위해서는 Waldron 등 (18)이 사용한 primer의 염기서열에 따라서 제작하였다 (Table 1).

PCR 반응 혼합액은 AccuPower PCR Premix Kit (Bioneer, Seoul, Korea)를 사용하여, DNA 시료 $(25 \mathrm{ng}) 0.5 \mu \mathrm{l}$, primer $(10 \mathrm{pM})$ 를 각각 $1 \mu \mathrm{l}$ 넣고 증류수로 최종 부피 $20 \mu \mathrm{l}$ 가 되게 하였다. $m e c \mathrm{~A}$ 를 증폭하기 위한 $\mathrm{PCR}$ 반응조건은 $94^{\circ} \mathrm{C} 30$ 초, $55^{\circ} \mathrm{C} 30$ 초, $72^{\circ} \mathrm{C} 1$ 분의 과정으로 30 회 반복하 였고, 마지막으로 $72^{\circ} \mathrm{C}$ 에서 7 분 연장으로 $\mathrm{PCR}$ 를 종결하 였다. 증폭된 DNA 시료는 $1.5 \%$ agarose gel을 통하여 전 기영동을 실시하였고, 각 증폭산물의 크기와 염기서열분 석을 통하여 $m e c \mathrm{~A}$ 유전자가 증폭되었음을 확인하였다.
그리고 $\mathrm{SCCmec}$ 유전자형을 결정하기 위한 $\mathrm{A}, \mathrm{B}, \mathrm{C}, \mathrm{D}, \mathrm{E}$, $\mathrm{F}, \mathrm{G}, \mathrm{H}$ 영역에 해당되는 primer를 이용한 PCR 반응조건 은 $94^{\circ} \mathrm{C}$ 에서 5 분간 초기 반응, 반복조건은 $94^{\circ} \mathrm{C} 30$ 초, $58^{\circ} \mathrm{C} 30$ 초, $72^{\circ} \mathrm{C} 1$ 분의 과정을 30 회 반복하였으며, 마지 막으로 $72^{\circ} \mathrm{C}$ 에서 7 분 연장으로 $\mathrm{PCR}$ 를 종결하였다. 증폭 된 DNA 시료는 $1.5 \%$ agarose gel을 통하여 전기영동을 실시하였고, 각 증폭산물의 크기와 염기서열분석을 통 하여 $\mathrm{SCCmec}$ 유전자가 증폭되었음을 확인하였다. SauI complex 유전자인 $h s d M, h s d R, h s d S$ 에 대한 primer를 이용 한 PCR 반응조건은 반복조건만 $94^{\circ} \mathrm{C} 30$ 초, $53^{\circ} \mathrm{C} 30$ 초, $72^{\circ} \mathrm{C} 2$ 분의 과정을 30 회 반복하였다. 증폭된 $\mathrm{DNA}$ 시료 는 $1.0 \%$ agarose gel을 통하여 전기영동을 실시하였고, 각 증폭산물의 크기와 염기서열분석을 통하여 SauI complex 유전자가 증폭되었음을 확인하였다.

\section{결 과}

\section{S. aureus coagulase type별 항생제 내성 비교}

S. aureus coagulase serotype별 세포벽 합성을 방해하는 대표적인 항생제를 중심으로 항생제 감수성 검사결과는 Table 2와 같았다. Coagulase serotype I, VI, VIII은 oxacillin (methicillin)과 cefoxitin에 감수성을 보여 모두 MSSA 표 현형으로 나타났다. 이중 coagulase serotype I은 penicillin 에 감수성을 나타내었으나, coagulase VI형과 VIII형은 penicillin에 내성을 나타내었다. Coagulase serotype II, III, IV, V, VII은 penicillin과 methicillin에 내성을 나타내었으 며, coagulase serotype $\mathrm{V}$ 만 cefoxitin에 감수성형과 내성형 이 관찰되었다. MRSA나 MSSA는 모든 균주가 vancomycin과 teicoplanin에 감수성을 나타내었다.

Table 2. CLSI disk diffusion antimicrobial susceptibility of S. aureus isolates according to coagulase types

\begin{tabular}{lcccccccc}
\hline \hline \multirow{2}{*}{ Antimicrobial disk } & \multicolumn{7}{c}{ Coagulase type } \\
\cline { 2 - 8 } & $\mathrm{I}$ & $\mathrm{II}$ & $\mathrm{III}$ & $\mathrm{IV}$ & $\mathrm{V}$ & $\mathrm{VI}$ & $\mathrm{VII}$ & $\mathrm{VIII}$ \\
\hline Penicillin & $\mathrm{S}$ or R & $\mathrm{R}$ & $\mathrm{R}$ & $\mathrm{R}$ & $\mathrm{R}$ & $\mathrm{R}$ & $\mathrm{R}$ & $\mathrm{R}$ \\
Methicillin & $\mathrm{S}$ & $\mathrm{R}$ & $\mathrm{R}$ & $\mathrm{R}$ & $\mathrm{R}$ & $\mathrm{S}$ & $\mathrm{R}$ & $\mathrm{S}$ \\
Cefoxitin & $\mathrm{S}$ & $\mathrm{R}$ & $\mathrm{R}$ & $\mathrm{R}$ & $\mathrm{S}$ or R & $\mathrm{S}$ & $\mathrm{R}$ & $\mathrm{S}$ \\
Vancomycin & $\mathrm{S}$ & $\mathrm{S}$ & $\mathrm{S}$ & $\mathrm{S}$ & $\mathrm{S}$ & $\mathrm{S}$ & $\mathrm{S}$ & $\mathrm{S}$ \\
Teicoplanin & $\mathrm{S}$ & $\mathrm{S}$ & $\mathrm{S}$ & $\mathrm{S}$ & $\mathrm{S}$ & $\mathrm{S}$ & $\mathrm{S}$ & $\mathrm{S}$ \\
\hline
\end{tabular}

R: resistant, S: susceptible 


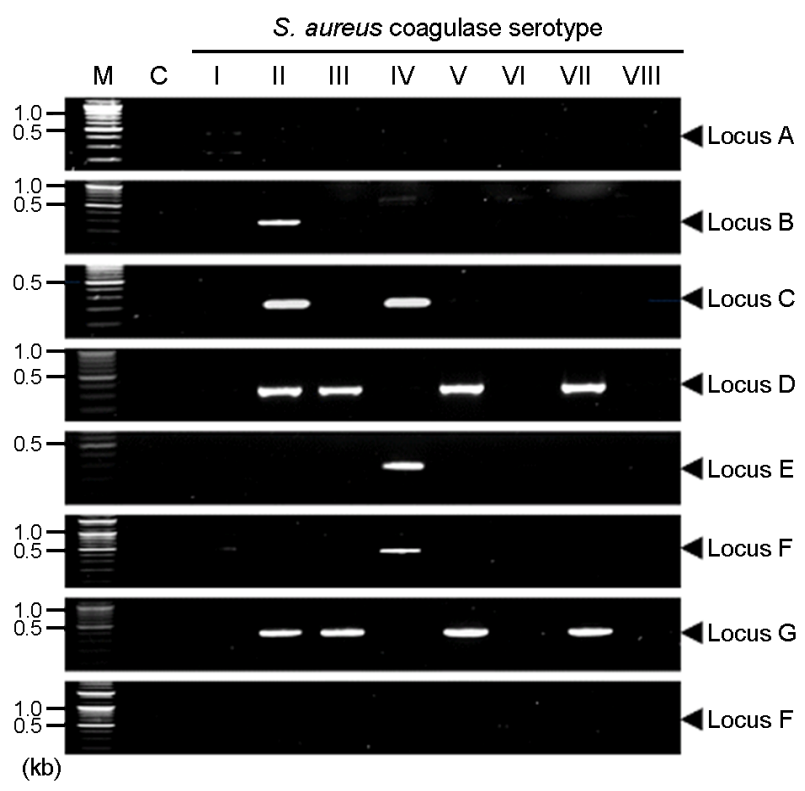

Figure 1. Agarose gel electrophoresis of DNA fragment amplified from the SCCmec (locus A, B, C, D, E, F, G, H) by PCR with specific primers. Lane M: the marker (100 bp plus DNA ladder), lane C: S. aureus (ATCC25923), the molecular size of locus A to H are 495 bp, 284 bp, 209 bp, 342 bp, 243 bp, 414 bp, $381 \mathrm{bp}$ and $303 \mathrm{bp}$, respectively.

\section{Methicillin 내성 균주로부터 SCCmec 유전자형 분류}

MSSA 중에서 coagulase type에 따라 mecA 유전자를 가지고 있어 이에 대한 $\mathrm{SCCmec}$ type을 확인하려고 $\mathrm{SCCmec}$ type을 분류할 수 있는 A-H 영역에 대한 특이 primer를 이용하여 PCR을 실시한 결과, MRSA로 판명된 coagulase type II, III, IV, V, VII은 SCCmec type II, IV, III, IV, IV로 판명되었으나, MSSA 분리주인 coagulase serotype I, VI, VIII에서는 SCCmec type을 분류하기 위한 A-H 영역 에 대한 특이 primer로 증폭산물이 생기지 않아 $\mathrm{SCCmec}$ type 분류가 불가능하였다 (Fig. 1).

\section{5종류의 Sau1 R-M complex}

Sau1 R-M complex에 해당되는 세 개의 유전자 Saul$h s d M(M 1, M 2),-h s d R(R 1, R 2),-h s d S(S 1, S 2)$ 에 대한 특이 primer를 이용한 PCR 결과, 8 개의 coagulase serotype에 서 Sau1 complex는 크게 다섯 종류 (M1, $\mathrm{R}_{2} \mathrm{M} 2, \mathrm{R} 2 \mathrm{M} 2$, $\mathrm{R}_{2} \mathrm{M} 2 \mathrm{~S} 1, \mathrm{R} 2 \mathrm{M} 2 \mathrm{~S} 2$ )가 검출되었다. 즉 M1형은 saulhsdM1 유전자만 검출된 형, $\mathrm{R}_{2} \mathrm{M} 2$ 형은 saulhsdR2와 saulhsdM1-2 유전자가 검출된 형, R2M2형은 saulhsdR1-2와 saulhsdM12 유전자가 검출된 형, $\mathrm{R}_{2} \mathrm{M} 2 \mathrm{~S} 1$ 형은 saulhsdR2, saulhsdM1-

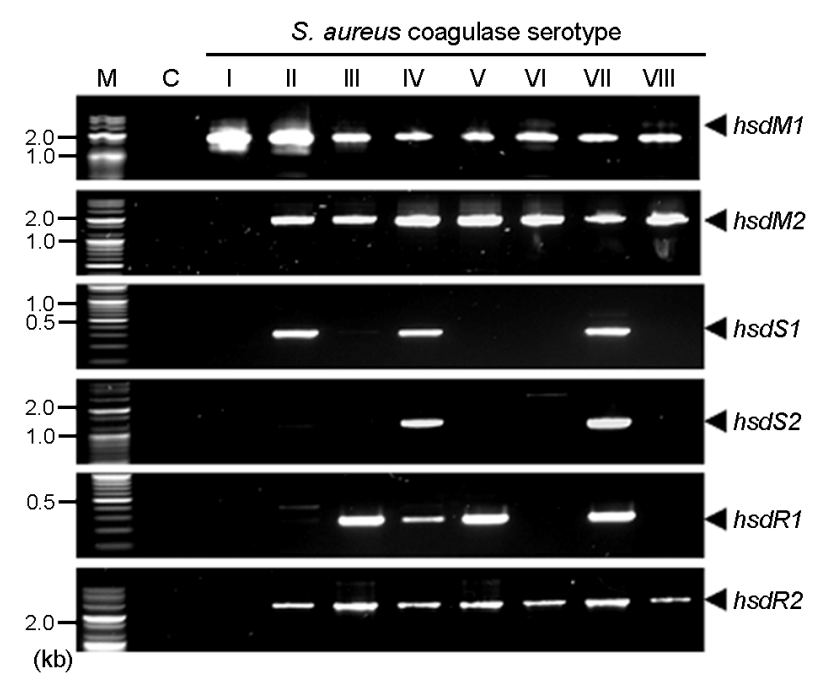

Figure 2. Agarose gel electrophoresis of DNA fragment amplified from the Saul ( $h s d M, h s d R, h s d S$ ) gene by PCR with specific primers. Lane M, 100 bp plus DNA ladder marker, lane C: S. aureus (ATCC25943), the molecular size of $h s d M 1, M 2, S 1$, $S 2, R 1$ and $R 2$ are 1,577 bp, 1,535 bp, 2,810 bp, 258 bp, 327 bp and $1,220 \mathrm{bp}$, respectively.

2와 saulhsdS1 유전자가 검출된 형, $\mathrm{R} 2 \mathrm{M} 2 \mathrm{~S} 2$ 형은 saulhsdR1-2, saulhsdM1-2와 saulhsdS1-2 모든 유전자가 검출된 형이다 (Fig. 2).

Sau1 R-M complex와 coagulase serotype과의 상 관관계

외래 유전자 전이, 특히 항생제 내성 유전자 전이 시 type 1 R-M 역할을 하는 Saul R-M complex type들을 coagulase type별로 분석하였다. 8 개의 coagulase serotype에 5 종류의 Saul complex가 서로 독특하게 연결이 되어 있 음이 확인되었다. saulhsdMl은 임상에서 분리된 모든 S. aureus coagulase serotype에서 검출되었으나, 표준균주 에서는 검출되지 않았다. Saul-hsdM2 type은 coagulase serotype I에서만 검출되지 않았으며, SaulhsdS1과 hsdS2 는 MSSA로 판명된 coagulase serotype I, VI과 VIII형에 서는 검출되지 않았으며, MRSA 중에서는 coagulase serotype II, IV, VII에서 S1 type이 검출되었으며, S2 type은 coagulase serotype IV와 VII에서만 검출되었다. SaulhsdR 유전자 중 R1 type은 coagulase serotype I에서만 검출되지 않았으며, R2 type은 coagulase serotype III, IV, V, VII에서만 검출되었다. 즉, coagulase serotype I은 M1, serotype VI과 VIII은 $R_{2} M 2$, serotype II는 $\mathrm{R}_{2} \mathrm{M} 2 \mathrm{~S} 1$, serotype IIII과 V는 $\mathrm{R} 2 \mathrm{M} 2$, serotype IV와 VII은 R2M2S2로 판명되었으며, 
Saul R-M complex type은 coagluase type별로 상관성이 있 음이 확인되었다 (Fig. 2, Table 3).

Sau1 R-M complex와 SCC mec 유전자형과의 상관 관계

Saul R-M complex 유전자형과 methicillin 내성과의 상 관관계를 알아본 바, Table 3에 있는 바와 같이 상호 연 관성이 있음이 확인되었다. MSSA는 Saul complex 중 M1 또는 $\mathrm{R}_{2} \mathrm{M} 2$ 이었으며, MRSA는 R2M2, $\mathrm{R}_{2} \mathrm{M} 2 \mathrm{~S} 1, \mathrm{R} 2 \mathrm{M} 2 \mathrm{~S} 2$ 로 나타났다. Sau1 R-M complex 중 DNA의 제한효소로부터 DNA 메칠화에 의해 보호하는 $s a u l h s d M$ 중 SaulhsdM1 은 MSSA나 MRSA에 관계없이 가지고 있음이 확인되 었다. MSSA는 SaulhsdS 유전자는 검출되지 않았으며, SaulhsdR 유전자는 SCCmec type VI과 VIII에서 SaulhsdR2 유전자만 검출되었다.

SCCmec type별로 Saul R-M complex type을 비교해 보 면, SCCmec type II는 $\mathrm{R}_{2} \mathrm{M} 2 \mathrm{~S} 1$, SCCmec type III는 R2M2, $\mathrm{SCCmec}$ type IV형은 R2M2, R2M2S2로 나타내어 SCCmec type III과 IV 모두 saulhsdM1, saulhsdM2, saulhsdR1, saulhsdR2 유전자를 가지고 있었다. SCCmec type별로 Saul R-M complex genotype과 특이성이 있음이 관찰되 었다.

Table 3. Summary of relationship of Saul R-M type, coagulase type, SCCmec type, and methicillin susceptibility

\begin{tabular}{lccccc}
\hline \multirow{2}{*}{ Types } & \multicolumn{5}{c}{ Sau1 R-M type } \\
\cline { 2 - 6 } & M1 & R$_{2}$ M2 & R2M2 & R$_{2}$ M2S1 & R2M2S2 \\
\hline Coagulase type & I & VI, VIII & III, V & II & IV, VII \\
SCCmec type & ND & ND & III, IV & II & IV \\
Methicillin type & MSSA & MSSA & MRSA & MRSA & MRSA \\
\hline
\end{tabular}

\section{고 찰}

S. aureus는 건강인의 비강이나 피부에 집락화하며 병 원 및 지역사회의 감염증의 중요한 원인균이다. MRSA 균주의 증가와 세포독성인자의 생성 및 MRSA에 vancomycin 내성 유전자의 삽입으로 기인된 superbacteria의 출현으로 인하여 치료에 어려움은 물론 치명적인 사례의 보고가 급증하고 있다 $(19,20)$.

우리나라 사람에서 가장 많이 분리되는 MSSA의 coagulase serotype은 I에서 VIII 중 VII, V, IV, II형, IIII, I 순이었으며, 2000년 이후 I, II형은 감소하고 V형이 증가 하고 있다 (13). Coagulase serotype VII은 시기별로 영향 받지 않고 가장 많이 검출되는 혈청형이다. Hwang 등의 보고 (13)에 따르면 시기 변화에 따라 coagulase serotype III형 MRSA의 분리율이 1994년에는 27.0\%에서 2005년 에는 $0.9 \%$ 로 감소하였으나, coagulase serotype V형은 1994 년 $0.0 \%$ 에서 2005년 18.5\%로, coagulase serotype VII도 $0.0 \%$ 에서 $4 \%$ 이상으로 급격히 증가하였으며, 근래 분 리된 MRSA의 coagulase형별 빈도는 II, IV, V, VII, III의 순이었다. 이러한 결과는 시기에 따라서 새로운 MRSA 유행균주가 출현하여 coagulase serotype, 다약제 내성 (SCCmec) 및 내성 유전자 전이에 관련된 특이효소와 관련이 있음을 알 수 있다.

Sau1 R-M system은 type 1 R-M system으로 다른 세균 들의 R-M system과 상동성이 높다고 보고되었다. Saul R-M complex는 한 copy의 saulhsdR, 두 copy의 saulhsdM, saulhsdS, 유전자에 의해 형성된 단백질들이 복합체 구 성에 의하여 $\mathrm{M} 2 \mathrm{~S}$ 또는 R2M2S 형태로 구성되어 있다 고 보고되었는데 (17), 본 연구에서는 다섯 가지 형태의

\section{A}

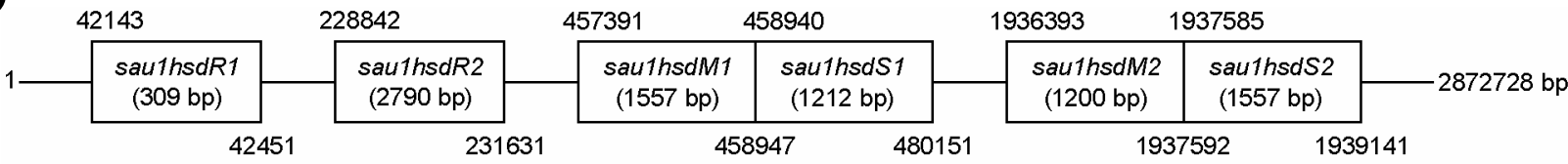

B

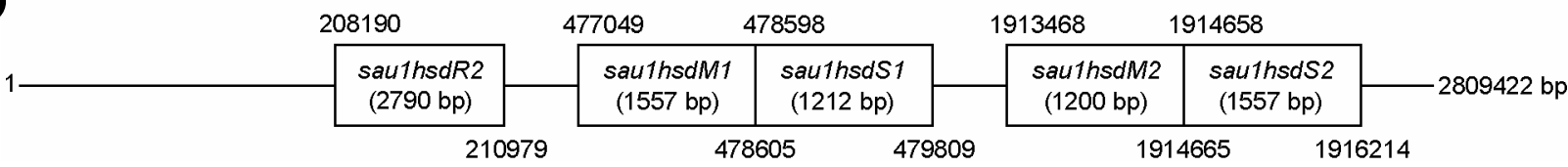

Figure 3. Genetic maps of type 1 Restriction and Modification system of S. aureus (A). S. aureus (USA_TCH1516) strain, (B). S. aureus (COL) strain. 
Sau1 R-M system이 발견되었다. 최근 Waldron과 Lindsay (18)는 S. aureus (USA_TCH1516) strain의 전체 genome 중 hsd 유전자 분석에서 크기는 다르지만 두 copy의 $s a u l h s d R$ 유전자가 확인되었음을 보고하였다 (Fig. 3). 따라서 본 연구에서는 6 개의 유전자에 대하여 $\mathrm{PCR}$ 를 수행하였으며, coagulase serotype별로 M1, R2M2, R2M2, $\mathrm{R}_{2} \mathrm{M} 2 \mathrm{~S} 1, \mathrm{R} 2 \mathrm{M} 2 \mathrm{~S} 2$ 형이 관찰되어 새로운 Sau1 R-M complex type이 관찰되었다. 특히 $\mathrm{MSSA}$ 에서는 $\mathrm{M} 1$ 형과 $\mathrm{R}_{2} \mathrm{M} 2$ 형으로, $\mathrm{M} 1$ 형은 methcillin은 물론 penicillin에 감수 성인 coagulase serotype 1 형이 해당되었으며, $\mathrm{R}_{2} \mathrm{M} 2$ 형은 methicillin에는 감수성이지만 penicillin에는 내성인 MSSA 로 coagulase serotype VI과 VIII이 해당되었다.

MRSA Sau1 type은 R2M2, $\mathrm{R}_{2} \mathrm{M} 2 \mathrm{~S} 1, \mathrm{R} 2 \mathrm{M} 2 \mathrm{~S} 2$ 형이 관찰 되어 $\mathrm{R}, \mathrm{M}, \mathrm{S}$ 를 모두를 가지고 있거나 $\mathrm{R}$ 과 $\mathrm{M}$ 만을 가지 고 있으면 해당되는 saulhsdM1, saulhsdM2, saulhsdRl, $s a u 1 h s d R 2$ 유전자를 가지고 있었다. Sau1 R2M2S2형은 coagulase serotype IV과 VII 및 SCCmec IV가 속하며, $\mathrm{SCCmec} \mathrm{IV형} \mathrm{중} \mathrm{일부는} \mathrm{R2M2형으로} \mathrm{coagulase} \mathrm{serotype}$ $\mathrm{V}$ 로 cefoxitin에 감수성형과 내성형이 해당된다. R2M2형 에는 SCCmec III형인 coagulase serotype III도 속하는데 근래에 coagulase serotype III는 감소하고 $\mathrm{V}$ 는 증가하는 데 같은 Sau1 R-M complex R2M2안에서의 변화가 관찰 되었다 $(7,13)$. Sau1 R1M2S1형은 coagulase serotype II와 $\mathrm{SCCmec}$ type II형으로 시기에 상관없이 가장 높은 검출 율을 나타내고 있다. 항생제 내성 유전자 전이의 민감성 과 관련이 있는 Sau1 R2M2S2형은 최근 분리율이 증가하 고 있으며, 다약제 내성을 보이는 coagulase serotype IV과 VII으로 앞으로도 계속 분리율이 증가할 것으로 추정된 다 $(7,13)$.

Coagulase serotype별로 SCCmec type 및 SauI R-M complex type이 상호 관련이 있음이 확인되었으며, 특히 Saul R-M complex type이 항생제 내성과 연관성이 있음이 확인되었다. 앞으로 SauI R-M complex type별로 유전자 전 이 및 유전자 삽입에 어떠한 영향을 미치는 지에 대한 연구를 수행하여 coagulase serotype과 SauI1R-M complex type에 따라 왜 SCCmec type이 다르게 나타나는 지에 대 한 정확한 기전을 밝힐 것이다.

\section{참 고 문 헌}

1) Archer GL, Mayhall CG. Comparison of epidemiologic markers used in investigation of an outbreak of methicillin resistant Staphylococcus aureus infections. J Clin Microbiol 1983;18:395-9.

2) Bouvet A, Fournier JM, Audurier A, Branger C, Orsoni A, Girard C. Epidemiological markers for epidemic strain and carrier isolates in an outbreak of nosocomial oxacillin-resistant Staphylococcus aureus. J Clin Microbiol 1990;28:1338-41.

3) Daum RS, Ito T, Hiramatsu K, Hussain F, Mongkolrattanothai $\mathrm{K}$, Jamklang M, et al. A novel methicillin-resistance cassette in community-acquired methicillin-resistant Staphylococcus aureus isolates of diverse genetic backgrounds. J Infect Dis 2002;186:1344-7.

4) Diep BA, Carleton HA, Chang RF, Sensabaugh GF, Perdreau Remington F. Roles of 34 virulence genes in the evolution of hospital-and community-associated strains of methicillinresistant Staphylococcus aureus. J Infect Dis 2006;193:1495 $-503$.

5) Kilic A, Li H, Stratton CW, Tang YW. Antimicrobial susceptibility patterns and staphylococcal cassette chromosome mec types of, as well as Panton-Valentine leukocidin occurrence among, methicillin-resistant Staphylococcus aureus isolates from children and adults in middle Tennessee. J Clin Microbiol 2006;44:4436-40

6) Barber M. Methicillin-resistant staphylococci. J Clin Pathol 1961;14:385-93.

7) Cha EK, Chang KS, Hwang SM. Correlation between staphylococcal cassette chromosome mec type and coagulase serotype of methicillin-resistant Staphylococcus aureus. J Bacteriol Virol 2009;39:71-8.

8) Tomasz A, Nachman S, Leaf H. Stable classes of phenotypic expression in methicillin-resistamt clinical isolates of Staphylococci. Antimicrob Agents Chemother 1991;35:124-9.

9) Durand G, Bes M, Meugnier H, Enright MC, Forey F, Liassine $\mathrm{N}$, et al. Detection of new methicillin-resistant Staphylococcus aureus clones containing the toxic shock syndrome toxin 1 gene responsible for hospital- and community-acquired infections in France. J Clin Microbiol 2006;44:847-53.

10) Johnson WM, Tyler SD, Ewan EP, Ashton FE, Pollard DR, Rozee KR. Detection of genes for enterotoxins, exfoliative toxins, and toxic shock syndrome toxin 1 in Staphylococcus aureus by the polymerase chain reaction. J Clin Microbiol 1991;29:426-30.

11) Kanemitsu K, Yamamoto H, Takemura H, Kaku M, Shimada J. Relatedness between the coagulase gene 3'-end region and 
coagulase serotypes among Staphylococcus aureus strains. Microbiol Immunol 2001;45:23-7.

12) Watanabe S, Ito T, Takeuchi F, Endo M, Okuno E, Hiramatsu K. Structural comparison of ten serotypes of staphylocoagulases in Staphylococcus aureus. J Bacteriol 2005;187:3698-707.

13) Hwang SM, Kim TU. Changes in coagulase serotype of Staphylococcus aureus isolates in Busan, 1994-2005. Korean J Microbiol 2007;43:346-50.

14) Lee M, Chong Y. Characteristics of methicillin-resistant Staphylococcus aureus isolated from wounds in Korean patients. J Infect Chemother 1996;2:130-5.

15) Lindsay JA, Holden MT. Staphylococcus aureus: superbug, super genome? Trends Microbiol 2004;12:378-85.

16) Lindsay JA, Moore CE, Day NP, Peacock SJ, Witney AA, Stabler RA, et al. Microarrays reveal that each of the ten dominant lineages of Staphylococcus aureus has unique combinations of surface associated and regulatory genes. J Bacteriol 2006;188:669-76.

17) Murray NE. Type I restriction systems. sophisticated molecular machines (a legacy of Bertani and Weigle). Microbiol Mol Biol Rev 2000;64:412-34.

18) Waldron DE, Lindsay JA. Sau1: a novel lineage-specific type I restriction-modification system that blocks horizontal gene transfer into Staphylococcus aureus and between $S$. aureus isolates of different lineages. J Bacteriol 2006;188:5578-85.

19) Périchon B, Courvalin P. VanA-type vancomycin-resistant Staphylococcus aureus. Antimicrob Agents Chemother 2009; 53:4580-7.

20) DeLeo FR, Chambers HF. Reemergence of antibiotic-resistant Staphylococcus aureus in the genomics era. J Clin Invest 2009;119:2464-74. 